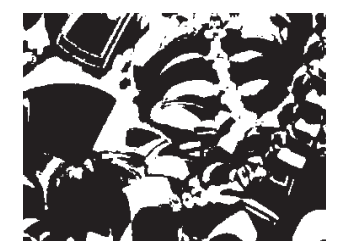

\title{
NATIONAL INNOVATION SYSTEM: WHERE DO GOVERNMENT AND BUSINESS DIVERGE?
}

Ernest VLAČIĆ

NOVAMINA Innovative Technology Center, Zagreb

ALGEBRA College, Zagreb

Marina DABIĆ

Faculty of Economics and Business, Zagreb

Nottingham Business School, Nottingham, UK

Zoran ARALICA

Institute of Economics, Zagreb

UDK: $354(497.5): 338.2$

$$
\text { 658(497.5):354 }
$$

Izvorni znanstveni rad

Primlieno: 31. 3. 2018.

The paper investigates the national innovation system and divergences in the prioritisation of key measures of the national institutional framework linked to the policy mix supply side. Two acting populations from the Republic of Croatia were selected for this process: on one side, 33 governmental representatives of the institutional framework (IF) ecosystem, and the "opposite side" of 93 owners or CEOs of firms as policy targets or beneficiaries. The produced results were additionally verified through 18 semi-structured interviews with government officials as representatives of the IF. The results confirm the existence of divergences in the perception of importance and relevance of the policy measures between the two populations.

Keywords: National Innovation System - NIS, policy, supply side, Croatia

$\triangle \quad$ Marina Dabić, Faculty of Economics and Business, Trg J. F. Kennedyja 6, 10000 Zagreb, Croatia.

E-mail: mdabic@net.efzg.hr

Nottingham Business School, Nottingham Trent University, Burton Street, Nottingham, NG1 4BU, United Kingdom.

E-mail: marina.dabic@ntu.ac.uk 
In the last twenty-five years, being a Central and Eastern European (CEE) country, the Republic of Croatia has experienced several socio-economic systematic changes that have influenced its R\&D and innovation performance. Croatian firms are evidently relatively weak performers in terms of innovation outputs, even though the human capital and educational system is fairly developed (EIS, 2017). In order to understand and address such an unfavourable position, the focus of this research is aimed towards two key actors of the national innovation ecosystem in Croatia. The first are firms, representing an actor that generates innovative commercial outputs, and the second is the institutional framework (the policy makers) which supports firms throughout the policy mix of measures. Under the policy mix term, we consider the idea of the departure from focusing on a single instrument and single optimal policy model, towards accepting the idea that the optimal policy model should be focused on the appropriate mix of policy instruments. The policy mix literature has a focus on the need to understand and address the specific needs and challenges in the innovation system in order to design the appropriate mixes of instruments. Regarding this, we consider the policy mix of measures as a combination of various types of instruments that appear in policy practice.

In the abovementioned relation among various stakeholders, several questions usually arise. What is the level of appropriateness and balance of policy mix measures for the targeted firm population and their operating innovation environment, and what is the gap, if any, between them? To avoid ambiguity, this research focuses primarily on policy mix supply-side measures. The main reason for this lies in the fact that the development of the demand-side of innovation policy is still in its initial phase in CEE countries. Therefore, the analyses of innovation policy cover mainly the supply side of innovation policy programmes and policy instruments.

In this research, we are interested in the question: Does the institutional framework promote a sufficiently well-tailored 'cocktail' of innovation support measures to its firms' needs? So, the principle goal of this paper is to measure the difference in the perception and prioritisation of currently active policy actions and instruments between two system components to understand the current gap. Thus, the overall research question develops: is there a notable divergence in the prioritisation of relevance of the innovation policy mix supply-side measures between firms and the institutional framework. Such a potential discrepancy and imbalance in perception might also be a reflection of governmental and systemic failures within the policy mix, which leads to fewer innovation outputs and a potentially higher rate of market failures at the firm level. 
DRUŠ. ISTRAŽ. ZAGREB GOD. 27 (2018), BR. 4 STR. $649-669$

VLAČIĆ, E., DABIĆ, M. ARALICA, Z NATIONAL...
In our mixed qualitative and quantitative methodology, we have translated current policy mix instruments and their measures into a set of critical success factors (CSFs) and confronted their importance in terms of perceptions within the firms and among the relevant representatives of the institutional framework. A quantitative statistical analysis of the survey data has provided information on the differences of the evaluated factors in each of the two main actors of an innovation system, and on whether there is a statistical significance in measuring the difference between the two. The quantitative results were supported by the qualitative investigation based on interviews with selected public sector representatives. In addition, the combination of quantitative/qualitative analysis was also used as complementary information for recommendations.

This paper is organised into four sections. Firstly, the literature and concepts related to the research aim are briefly discussed. The research methods are then employed and the data are used to describe the research problem. Further, the results are shown and followed by practical recommendations. Finally, the conclusions and implications of the study are laid out.

\section{THEORETICAL BACKGROUND}

\section{Governments supporting innovation: policy mix}

There is a comprehensive consensus among scientists that innovation represents a source of competitive advantage of firms (Ireland \& Webb, 2007), whereby the national institutional frameworks regularly support them within their shared innovation ecosystems (Isenberg, 2010; Spigel, 2017). The research gap in the analytical analysis of systematic problems in innovation policy is discussed by Perrels (2001), Edquist (2005, 2011), Edler and Fagerberg (2017), Mazzucato and Semieniuk (2017), and innovation policy in CEE countries in the works of Svarc (2006) and Bartlett (2014).

We argue that the representatives of the institutional framework have a different view from CEOs of firms on the list of priorities and critical factors regarding R\&D and innovation policies that may impinge on medium to long-term firms' productivity. These are primarily, but not limited to, R\&D investments, investments in science-technology infrastructure, the issue of skills, as well as network measures.

Innovation outputs and efficiency within national innovation systems rely on various types of links among actors (firms, academia, intermediaries) (Van Der Borgh, Cloodt, \& Romme, 2012; Hazelman, 2017), creating new knowledge-intensive enterprises, new technologies and knowledge (Radosevic \& Yoruk, 2013; Dabić, Razum, \& Brečić, 2016). A number of elements in 
DRUŠ. ISTRAŽ. ZAGREB GOD. 27 (2018), BR. 4, STR. $649-669$

VLAČIĆ, E., DABIĆ, M. ARALICA, Z. NATIONAL..

(1) TABLE 1

Principle policy

measures of the supply-side and the demand-side policy, (adapted from OECD,

2012 p. 155 and $\mathrm{Ma}$ et al. 2016, p. 1056) the innovation system does not operate efficiently, which results in systemic or market failures, thereby motivating government intervention to support research and development (Brautzsch, et al., 2015), research co-operation (Becker \& Dietz, 2004), knowledge sharing between firms (Kiessling, Richey, Meng, \& Dabić, 2009; Mulrow, Derrible, Ashton, \& Chopra, 2017) or between firms and universities (Meissner \& Carayannis, 2017).

Governments seek to stimulate innovation at different operating levels and consequently use different supportive measures (Perrels, 2001) and innovation policy instruments in order to promote regional and national economic development (Landabaso \& Mouton, 2005; Howlett \& Rayner, 2007).

In pursuit of a particular policy goal, in this case the promotion of business R\&D and innovation, governments often use a different "policy mix" or a combination of instruments (Zhu, 2006; OECD, 2014; Durst \& Poutanen, 2013).

The selection of the most suitable tools and their design, according to the context and local specificities of an innovation system (Mercan \& Göktaş, 2011; Horbach, Rammer, \& Rennings, 2012), is critical in the favourable formulation of innovation policy instruments within an integrated policy mix (Borrás \& Edquist, 2013). "The role of the state in creating or assisting in creating lead markets mainly lies in the provision of the means to combine supply- and demand-side measures and supply- versus demand-side instruments" (OECD, 2012, p. 156). The principle elements of both sides within the governmental policy mix are presented in Table 1.

\begin{tabular}{ll}
\hline The demand-side policy & The supply-side policy \\
\hline Public procurement & $\begin{array}{l}\text { Public R\&D (funding, tax incentives and risk investment, } \\
\text { crowdfunding) }\end{array}$ \\
Regulations & $\begin{array}{l}\text { Strengthen scientific basis (infrastructure construction, research } \\
\text { centre, persona training and flow) }\end{array}$ \\
Cultivating leading market & $\begin{array}{l}\text { Information \& mediation (international technology) } \\
\text { Innovation from demand side }\end{array}$ \\
$\begin{array}{l}\text { Network measures (incubators and science and technology } \\
\text { parks, industry clusters etc.) }\end{array}$
\end{tabular}

According to Chicot and Mat (2015), innovation failures within the policy mix are categorised as demand-side failures, demand-supply interactions traps, and supply-side failures. We may also infer from the critical tone of policy documents that the principal driver is the notion that traditional supply-side innovation policies are insufficient to meet the challenges posed in promoting competitiveness (Edler \& Georghiou, 2007). For the purpose of this article, and to keep the research focus and limit its scope, a narrowly focused orientation on the supply side will be taken. 
DRUŠ. ISTRAŽ. ZAGREB GOD. 27 (2018), BR. 4 STR. $649-669$

VLAČIĆ, E., DABIĆ, M. ARALICA, Z NATIONAL...
This research is of special importance for Croatia given the perceivable dearth of literature that covers the examined field from the described topology perspective of "the supply and demand side" of the Croatian national policy mix. Research and technology policy in Croatia is fragmented and lacks a coherent and integrated policy framework (MINGO, 2016; JRC IPTS, 2015). Croatia is a moderate innovator according to the European Innovation Scoreboard (EIS, 2017), and ranks 26th out of 28 EU Member States with innovation performance score 0.3 , against the EU average of 1.0, and a negative score in innovation performance growth -0.9 .

\section{The research model}

In their work, Allocca and Kessler (2006) have also investigated the key CSFs that differentiated leading and dynamic from moderate innovators. Applying a similar approach in this research, the CSFs of firms will be firstly translated and then confronted with the perception of the institutional framework that currently manages and operationalises the national innovation policy mix.

Particular focus will be put on the instruments and measures that the national policy mix aims at its agents (firms) on the supply side. As specified in the objectives, the purpose of this research is to assess the amplitude and the extension in divergences within CSFs in the process of firms' innovation between firms and the institutional frameworks. Thus, according to the objective of the study and based on the literature review, we have established an overall research question: 'Is there a notable divergence in prioritisation relevance of innovation policy mix CSFs between the institutional framework and the firms as agents'?

We argue that such difference might hamper the inno-

(1) FIGURE 1

Research model, policy mix with extrapolated CSFs vative performance of firms and that, at the same time, it does not positively influence the mitigation of their market failures with innovative products/service market launches.

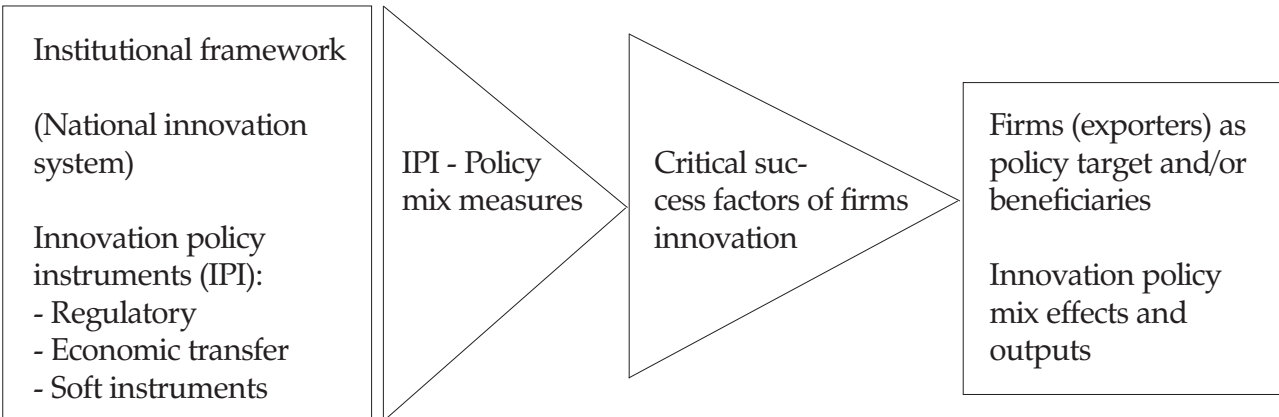




\section{METHODOLOGY}

The available literature demonstrates that scholars have been dealing with CSF prioritisation issues, although somewhat less in the field of innovation policy mixes. The examined theoretical background revealed a number of research projects accordingly, with several of them being primarily focused on CSF identification and selection (Komninos \& Tsamis, 2008; Osei-Kyei \& Chan, 2015; Wilson, 2015). Due to the lack of a perfectly matching methodology at our disposal, a tailored empirical and analytical methodology approach was constructed to meet the purpose of this research.

The methodology consists of a three-step quantitative and qualitative mixed methodological approach applied as follows: 1) definition and selection of adequate number of key success factors, 2) design and application of a survey on two key interacting populations and 3) statistical analysis of the collected data with qualitative confirmation.

The first step, the identification, definition and selection of an adequate number of CSFs is frequently methodologically induced by Pareto's heuristic approach (Craft \& Leake, 2002; Karuppusami \& Gandhinathan, 2006). The knowledge pool for the selection of CSFs consists of: a) previous studies and acquired knowledge of the theoretical context $b$ ) the current national operating environment c) insights from the 'Strategy for innovation encouragement of the Republic of Croatia 2014-2020' (MINGO, 2014), 'Smart Specialisation Strategy 2016-2020' (MINGO, 2016), and other available Croatian national documents dealing with innovation. As a result of the implementation of Pareto's synthesised approach, six critical success factors were extrapolated as shown in Table 2. It also includes a

(1) TABLE 2

Selected CSFs with descriptions brief interpretation of each factor that was also used in the distributed questionnaire.

No. CSF short name CSF description used in questionnaire

1 Availability of financing

availability of institutional (public) financial support for innovation in firms regardless of the amount, type and intensity
$2 \begin{aligned} & \text { Marketing } \\ & \text { support }\end{aligned}$
2 Marketing

3 Institutional incentives institutional (public) support and assistance (in any form) for the market (route-to-market support) release/launch of innovative products

4 Education on innovation adjustments and reduction of tax policy or provision of other institutional incentives for the innovating firms
Collaboration promotion and facilitation of collaboration with higher education and pub- with academia lic institutes to boost mutual benefits in efficient joint innovation activities
6 Intellectual support and organising towards a better understanding of the property protection of intellectual property rights (IPR - 'freedom to operate')


DRUŠ. ISTRAŽ. ZAGREB GOD. 27 (2018), BR. 4 STR. $649-669$

VLAČIĆ, E., DABIĆ, M. ARALICA, Z NATIONAL...

(1) FIGURE 2

Taxonomy of

innovation policy supply-side tools with allocated CSF,

adapted from J. Edler,

L. Georghiou (2007,

p. 953)

\begin{tabular}{|c|c|}
\hline $\begin{array}{c}\text { Equity } \\
\text { support }\end{array}$ & $\begin{array}{c}\text { Fiscal } \\
\text { measures }\end{array}$ \\
\hline CSF: 1 & CSF: 3 \\
\hline
\end{tabular}
The remaining non-selected factors/measures that belong to the supply side, such as networking-clustering (Vlačić, Tišma, \& Maleković, 2005) and technology transfer, influence innovation processes in firms as agents with significantly weaker impact.

The selected CSF is allocated and visible on Edler and Georghiou's (2007) modified taxonomy of innovation policy tools graph presented in Figure 2. It shows that practically all of the supply-side policy mix measures, as presented by the authors, are covered by the selected CSFs. This may also partially be valid for the networking factor that is partially covered by networking in the academic sector. However, in this particular study, it does not include trade associations, clusters, and other forms of innovation networking.

\begin{tabular}{|} 
| & \multicolumn{2}{|c|}{ Supply-side measures } \\
\hline Finance
\end{tabular}

A CSF ranking survey is constructed as a basis for the research operationalisation, and a questionnaire was launched to surveyed populations, the firms and the institutional framework. In order to produce an indispensable set of qualitative data, the institutional framework representatives were surveyed through direct visits using also the form of semi-structured interviews.

Sampling representativeness within the firms was achieved by selecting deliberate types, i.e. homogenisation was done by focusing on the population of technologically oriented firms. The survey was distributed through the authors' acquaintances to more than 600 firms that were involved in innovation processes focused on technology development. Although the quantity of return in today's survey-saturated situation was surprisingly high, 108 (above 18\%), the received number of relevant responses had to be slightly reduced by the number of incomplete responses. Finally, 93 nationwide relevant samples were used for statistical analysis. A segmented regionally based approach was considered inappropriate due to nation-wide uniform coverage of the governmental policy mix measures.

The institutional framework population sample was selected through a multi-criteria approach. The selected sample 
DRUŠ. ISTRAŽ. ZAGREB GOD. 27 (2018), BR. 4, STR. $649-669$

VLAČIĆ, E., DABIĆ, M. ARALICA, Z. NATIONAL..

(1) TABLE 3

IF sampling pattern with three-fold typology specified is represented by policy makers within the associated organisation-member of the institutional framework, which takes part in regular operations or is otherwise proactively involved in supporting the innovation process of firms. The criterion of mandatory proactive participation in the process is valid for both the institutional organisation and the identified person.

Also, a selected person was obliged to participate as the proactive participant, or to occupy a position in at least one of the following three categories, ideally all three; 1 ) decision making position, 2) opinion making position or 3) operationally or strategically professionally dealing with innovation in the firm's area of operation. As a result, four constitutive categories within the institutional framework were selected as a representative sample: 1) political and legal framework representatives, which includes representatives of ministries and their associated agencies, 2) R\&D and innovation institutions representatives who mainly operate within the academic community, which includes universities and public research institutes, 3) innovation activities funding providers representatives, irrespective of whether they are private or public, 4) innovation networking and other institutional support representatives. Finally, 20 institutions and their respective 33 highly positioned representatives who met the criteria and agreed to participate in the study were selected. With 20 available, relevant and complementary organisations, it can be inferred that the sample is reliable and representative. Table 3 shows the final institutional framework sampling pattern whose 33 highly ranked representatives were asked to fill in the questionnaire. These were additionally categorised into four categories and allocated to the typology of institutional frameworks innovation instruments (Borrás \& Edquist, 2013).

\begin{tabular}{|c|c|c|c|c|}
\hline Category & Candidate organisation & Abbrev. & $\begin{array}{l}\text { Typology Borrás, } \\
\text { Edquist (2013) }\end{array}$ & $\begin{array}{l}\mathrm{Nr} \text {. } \\
\text { particip. }\end{array}$ \\
\hline $\begin{array}{l}\text { political } \\
\text { and legal } \\
\text { framework }\end{array}$ & $\begin{array}{l}\text { Ministry of Economy, Ministry of } \\
\text { Science, State Intellectual Property } \\
\text { Office, Agency for Investments and } \\
\text { Competitiveness }\end{array}$ & PLF & $\begin{array}{l}\text { regulatory / eco- } \\
\text { nomic transfer }\end{array}$ & 8 \\
\hline $\begin{array}{l}\text { R\&D and } \\
\text { innovation } \\
\text { institutions }\end{array}$ & $\begin{array}{l}\text { Universities and Faculties, Institute } \\
\text { Ruđer Bošković, The Institute of } \\
\text { Economics, Zagreb, BRODARSKI } \\
\text { institute }\end{array}$ & R\&D & regulatory & 9 \\
\hline funding providers & HAMAG BICRO, ${ }^{1}$ CRANE - ZIP2 & FUND & economic transfer & 7 \\
\hline $\begin{array}{l}\text { innovation net- } \\
\text { working and } \\
\text { other } \\
\text { institutional } \\
\text { support }\end{array}$ & $\begin{array}{l}\text { Croatian Employers' Association, } \\
\text { Croatian Chamber of Economy, De- } \\
\text { velopment Agency Zagreb, Institute } \\
\text { Ivo Pilar, Technology Transfer Offices, } \\
\text { Croatian Bureau of Statistics }\end{array}$ & OTH & $\begin{array}{l}\text { soft instruments / } \\
\text { regulatory }\end{array}$ & 9 \\
\hline
\end{tabular}


DRUŠ. ISTRAŽ. ZAGREB GOD. 27 (2018), BR. 4 STR. $649-669$

VLAČIĆ, E., DABIĆ, M., ARALICA, Z NATIONAL...
Along with the survey distributed to the institutional framework representatives, 18 of them were additionally interviewed in the form of semi-structured interviews, which resulted in knowledge used for the validation of findings and construction of recommendations.

The statistical method for testing our research goal presupposes three sequential steps; a) creation of CSFs' ranking database of both populations, whose values are allocated from the most important ("1") to the least important ("6"), b) calculation of the arithmetic mean value of each of them on the basis of the responses received, c) applying Spearman's rank correlation coefficient to determine the statistical difference between the two populations.

Since this research deals with two different sample sizes of the ranked data, the determination of statistical significance is not directly applicable. Nevertheless, in order to determine the pair difference of a single factor, a twofold approach will be used. It consists of combining the arithmetic mean of each compared pair with their ranking difference, thus, besides the specific answer on research goal, each factor's divergence is provided as well.

\section{THE ANALYSIS OF THE RESULTS AND DISCUSSION}

\section{Findings}

(1) TABLE 4

Answers distribution of the IF representatives

The distribution of the collected answers of the institutional framework representatives is presented in Table 3, while a summarised integration of the results of all CSFs' responses, including those of firms, is presented in Table 4.

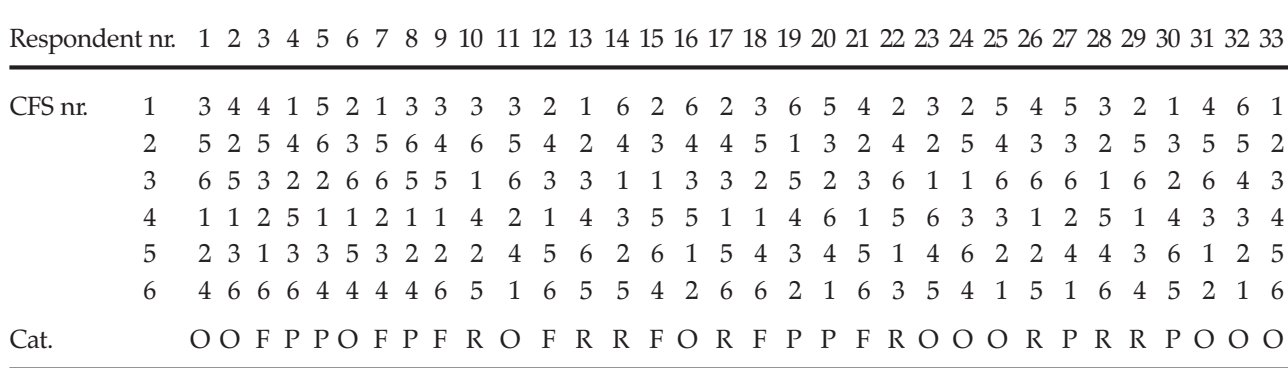

$\mathrm{R}=\mathrm{R} \& \mathrm{D}, \mathrm{F}=\mathrm{FUND}, \mathrm{P}=\mathrm{PoLeFr}, \mathrm{O}=\mathrm{OTH}$

Besides displaying the arithmetic mean values as a result of ranking, Table 5 additionally presents two other columns of data: the number of respondents (firms/representatives of institutional framework) who considered the evaluated factor as the most important and those who selected it as the least 


\begin{tabular}{|c|c|c|c|c|c|c|c|c|c|c|c|c|}
\hline $\begin{array}{l}\text { SF } \\
\text { number }\end{array}$ & CSF title & 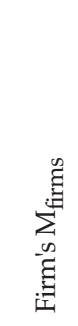 & 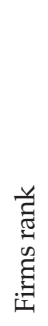 & 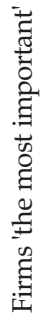 & 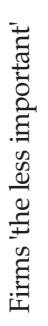 & $\sum_{\oplus}^{\omega}$ & $\begin{array}{l}\text { 荀 } \\
\text { 岂 }\end{array}$ & 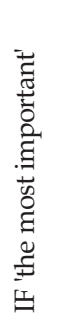 & 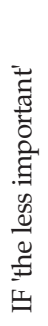 & 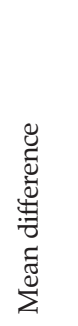 & 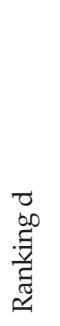 & 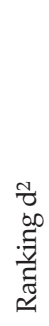 \\
\hline 1 & Availability of financing & 2,15 & 1 & 47 & 7 & 3,20 & 2 & 5 & 4 & 1,05 & 1 & 1 \\
\hline 2 & Marketing support & 3,15 & 3 & 5 & 7 & 3,80 & 5 & 1 & 3 & 0,65 & 2 & 4 \\
\hline 3 & Institutional incentives & 3,01 & 2 & 17 & 12 & 3,60 & 4 & 6 & 10 & 0,59 & 2 & 4 \\
\hline 4 & Education on innovation & 3,29 & 4 & 5 & 3 & 2,73 & 1 & 12 & 2 & $-0,56$ & -3 & 9 \\
\hline 5 & Collaboration with academia & 4,00 & 5 & 4 & 7 & 3,43 & 3 & 4 & 4 & $-0,57$ & -2 & 4 \\
\hline 6 & Intellectual property & 4,31 & 6 & 10 & 7 & 4,23 & 6 & 5 & 10 & $-0,08$ & 0 & 0 \\
\hline
\end{tabular}

(1) TABLE 5 Summary and comparison table of populations' questionnaire acquired results
To determine the statistical differences between the observed series, while all $n$ ranks are distinct integers, the Spearman rank correlation ${ }^{3}$ coefficient is applied on two CSF rankings according to the formula:

$\rho=1-\frac{6 \Sigma d_{i}{ }^{2}}{n\left(n^{2}-1\right)}$

- $d_{i}=\operatorname{rg}\left(X_{i}\right)-\operatorname{rg}\left(Y_{i}\right)$, is the difference between the two ranks of each observation

- $n$ is the number of observations, in this case $n$ ranks are distinct integers

In this case, $n=6, \Sigma d_{i}{ }^{2}=22$, and the calculated Spearman coefficient is $\rho=0.3714$. Taking into consideration the degrees of freedom number (31) and the resulting Spearman's coefficient value $(\rho=0.3714)$, by using a Spearman's ranking coefficient graph ${ }^{4}$ we note a fairly weak positive relationship between the two ranks. In other words, the existence of differences in prioritising the two observed series has been confirmed with a high confidence level. Particularly, the existence of differences in the prioritisation of the critical success factors between the two examined populations is evident.

The analytical results of this study have answered our research question, which suggests that there are differences in the prioritisation of the critical factors of innovation between Croatian companies and the institutional framework. Yet, it remains to be seen where and how these differences are manifested.

\section{Differences by CSFs}

The results in Table 4 show that the most important CSF by ranking to the examined population of firms is the "availability of funding", which drives and catalyses their innovation process when obtained directly. This particular CSF is ultimately considered as the most influential one in 47 out of 93 firms, which 
DRUŠ. ISTRAŽ. ZAGREB GOD. 27 (2018), BR. 4 STR. $649-669$

VLAČIĆ, E., DABIĆ, M. ARALICA, Z.: NATIONAL... is more than half of all surveyed firms (50.5\%). Through the eyes of the institutional framework, the "availability of funding" is placed in second position, with three respondents who consider the availability of innovation financing the most important factor for innovation success. These results may be interpreted in such a way that, in this particular period - the last decade, the institutional framework has not provided the Croatian firms with an appropriate well balanced portfolio of innovation funding instruments. The evaluated CSF "availability of funding" also includes and relates to the reduction of the administrative burden in the process of funding operationalisation as well as balancing the appropriate grant portion with the firm's own contribution.

The second in rank, according to firms, are fiscal "incentives" in the context of tax relief or other types of supporting instruments offered by the institutional framework, followed by the third ranking "support to marketing activities," or more precisely, assistance in guidance and support for international market penetration. Firms' education on innovation processes, and the importance of collaboration with academia and the R\&D community are placed in fourth and fifth places respectively. The least important of the surveyed CSFs for firms is the "intellectual property support". This factor gained the largest number of single respondents ranking it as the least important one, precisely 28 of them.

Quite adversely, the results of CSF's prioritisation of institutional framework representatives presented in Table 4 show that they consider "education on innovation" as the most important factor in supporting their innovation (12 highest rankings). Here again, similarly as with firms, more than a third of all respondents considered this CSF as the most important in achieving more efficient and more effective outputs from firms' innovative activities. This specific CSF contains the ingredients of all other five examined CSFs.

Next, "collaboration with academia" occupies the third place with four singling it out as the most important CSF. Finally, similarly to the firms' ranking, "intellectual property" is positioned in the last place with ten answers seeing it as the least important to the process.

Close to the "intellectual property" statistic, four respondents from the institutional framework selected the "incentives for innovation" as the least important factor. Members of the institutional framework explain that the output effect of this particular CSF can be effectively sensed only ex-post the innovation process. Their thesis is based on the fact that several countries have already modified their policy and are looking forward to reducing the incentives, or even abandoning them completely. 
DRUŠ. ISTRAŽ. ZAGREB GOD. 27 (2018), BR. 4, STR. $649-669$

VLAČIĆ, E., DABIĆ, M., ARALICA, Z. NATIONAL..

\section{IMPLICATIONS}

While observing the values of the column "RANKING $\mathrm{d}$ " shown in Table 4, the visible numeric difference among the different CSFs is noted. It mainly concerns the factor "education" (-3), followed by "marketing" (2), "collaboration with academia" (-2) and "incentives" (2). The full ranking alignment in prioritising has been achieved only with the "intellectual property" CSF that both populations deemed the least important one. This analysis evidently confirms that the differences in prioritising the "availability of funding" factor are relatively low, and this specific CSF is placed highly on the priorities of both observed populations. This aligned result can facilitate and catalyse the process of harmonising strategies and decision-making within the institutions towards national firms.

The results have confirmed differences in the prioritisation of the most influential policy mix measures in current operating conditions. In this light, national firms consider adequate and appropriate innovation financing measures as the most influential and important for their effective and quantitative innovating uptake. Such firms' preferences also confirm the inferred time persistence of the ongoing need for liquid capital as the major obstacle to fuel their innovation processes (Božić \& Rajh, 2016; Dodgson, 2017).

The deepest gap refers to "education" measures, which does not represent a particularly surprising outcome due to the institutional framework's behavioural nature. On the other hand, firms are not fully aware of the importance of insights into innovating practices expertise, particularly in the field of intellectual property. By ranking education highly, the IF suggests that an increase in knowledge and skills provided by focused education shall provide sustainability in the effectiveness of firms' innovation. Moreover, it will facilitate and enhance their access to a wide range of instruments focused on innovation funding available through external sources, including those of its own institutional framework.

A somewhat less prominent gap is identified with "market assistance" and "incentives measures", where the incentives are placed highly, in the second position by firms, and relatively low, in the fourth position, by the institutional framework. The members of the institutional framework claim that the output effects of this particular CSF may be effectively sensed only ' the innovation process, arguing that some countries have already modified their policies and look forward to reducing incentives or abandoning tax incentives.

Cooperation with academia is placed somewhere in the middle as a priority for both populations, and there are no wide 
DRUŠ. ISTRAŽ. ZAGREB GOD. 27 (2018), BR. 4 STR. $649-669$

VLAČIĆ, E., DABIĆ, M. ARALICA, Z.: NATIONAL... divergences determined with this CSF. Although this linkage represents a 'holy grail' of numerous academic, practitioner and policy level debates, the resulting diminished relevance is about the same for both examined populations. Apparently, the blame lies on both sides. On one side, there are firms that are not particularly interested in academia's services due to their specific portfolio of offerings and needs that per se do not demand its large-scale involvement. On the other side is academia that lacks sufficiently efficient and incentivising instruments and measures to motivate scientists and engineers to be proactively involved in cooperation with firms by delivering industrial research and innovation. The same is valid for different process phases, starting with assisting and facilitating generation of ideas and followed by pragmatic R\&D involvement. In addition, the economic measures managed by the institutional framework aiming to strengthen the academia-industry linkage are not sufficiently well balanced and coherently created to generate tangible benefits.

There are no particularly evident divergences determined in prioritising intellectual property rights measures. Both populations put them in the last, sixth place. This does not mean that the IPR in the national context is not a relevant issue; on the contrary, it is relevant, and both populations understand and accept it. Members of the institutional framework emphasise that understanding and managing intellectual property is extremely important and that it deserves specially focused attention, although in terms of priorities its ranking remains the lowest. The low IPR score of firms may also be related to their lower overall export and patent activities, which implies that no particular effort in dealing with intellectual property issues is needed to compete on the local market.

The main implication of this research is the requirement of the recognition of innovation policy needs within the policy sector, parallel with the recognition of innovation needs in the business sector. The recognition of the needs of different stakeholder groups leads to recognition of the importance of different dimensions of innovation policy. Innovation policy objectives, design, implementation and impact are the most important dimensions of innovation policies. The importance of the dimensions of innovation policy is different for each stakeholder group (policy sector, academia and business sector). For example, the implementation of innovation policy programmes is more important for participants from the business sector than for participants from the policy sector. The implementation of the innovation policy might lead to the commercialisation of innovation. These implications are in line with the system-oriented perspective of innovation, where the crucial 
element of functionalising of the innovation system is the degree of interaction between different parts of the system; the extent to which some vital components of the system are in need of improvement (Edler \& Fagerberg 2017).

RECOMMENDATIONS TO IMPROVE THE INSTITUTIONAL FRAMEWORK

The following recommendations were validated and shaped through the compiled results of the semi-structured interviews conducted with the institutional framework representatives as respondents. Firstly, the IF needs to be oriented to establishing a single policy coordination body that will be able to coordinate the national innovation ecosystem with a single and centralised position. "It is obvious that IF needs to challenge and optimise some measures and instruments (...). In that sense, it may not be necessary to change the quantity, but rather work on focusing on the quality, appropriateness, and balance of such instruments". (Respondents 9 and 10).

With regard to the particular measures examined within the scope of this research, the IF should optimise the economic-financial instruments with the aim to reduce overall administration burdens, appropriate grants vs. in-kind ratio, provide preconditions for better co-operation with the academia and be target specific with population/sectors/criteria according to trends and foresight suggested by the OECD (OECD, 2014). This should not be "operationalised in a simple coping mode of other apparently successful nations/environments, but these measures should rather be shaped while taking into account the specifics of the national environment". (Respondent 5).

Next, the intensity of formal IPR production required for granting permission/disbursement should be severely reduced, especially when the application for patents is concerned. "Patents are usually not the precondition or criteria for real life successful market penetration (...), but firms need to know how to protect them anyway" (Respondent 1).

Such a recommendation does not diminish the importance of the IPR, but it proposes the construction of an appropriate and well-balanced approach. It might include elements of awareness building and patent examination before the market launch, which is usually neglected and may be disastrous in certain cases.

When it comes to incentives in the form of taxes or other innovation measures, it represents a policy measures area that is arguably applied with different success in different environments. Croatia has abandoned a number of these category measures, such as tax relief or financial stimulations of suc- 
DRUŠ. ISTRAŽ. ZAGREB GOD. 27 (2018), BR. 4 STR. $649-669$

VLAČIĆ, E., DABIĆ, M., ARALICA, Z.: NATIONAL...

cessful applicants for EU funds. As per our recommendation, these may preferentially be re-established to focus on incentivising technology-based innovation, rather than praise all types of innovations including the business/process innovations in large corporate enterprises, as was the case of recent practices (Respondents 1 and 8 ).

Stimulating academia/industry collaborations is an important measure, but it needs to be understood how and when it is effective. The institutional framework should carefully study it and adapt these standards from both sides' perspectives with meaningful involvement of local stakeholders. Specific involvement of the Ministry of Science is also necessary here to promote an incentivising framework for scientists' proactive involvement (Respondents 1, 4, 7 and 15, 16).

To make the results of this work useful, it is necessary to reach an adequate level of visibility with both populations studied. It is particularly important that they present themselves as visible to the IF side due to their position and ability to act towards making the necessary changes, adaptations and improvements of policy measures, and thus contributing to the reduction of gaps.

Finally, although a relatively low priority in our study, market assistance measures should not be neglected and financial instruments even with a strong technology development accent should be adapted to finance the facilitation of firms in their market penetration.

\section{CONCLUSIONS}

Theoretical considerations, conceptualisation and operationalisation of innovation policy mixes are widely represented and discussed in the academic and practitioners' milieus, which is also true for Croatia, albeit at a significantly lower level of intensity. The extent of structured knowledge is rapidly decreased on the level of specific expert knowledge, such as supply and demand innovation policies, or other components of policy mix. Among other factors, there is a complete lack of codified knowledge and evidence on differences in standpoints between the government or the institutional framework on one side, and the firms' representatives, on the other side.

In this study, we have shown that there are statistically significant differences that create divergences in understanding the priorities and the importance of key policy mix measures. These measures, translated in the form of critical success factors, are mostly understandable and logical from the perspective of the acting position of both confronted populations.

As elaborated, the two examined groups differ in prioritisation of innovation measures CSFs, particularly in a top- 
DRUŠ. ISTRAŽ. ZAGREB GOD. 27 (2018), BR. 4, STR. 649-669

VLAČIĆ, E., DABIĆ, M. ARALICA, Z. NATIONAL.. -ranking position. Thus, firms are considering availability of innovation funding as the most important one, while representatives of the institutional framework are placing education first.

We may also conclude that the gap in the demonstrated divergences could be narrowed by redesigning the current policy measures and related strategies as part of the institutional framework's responsibility. Such optimisations and adaptations will doubtless catalyse and stimulate the creation of more efficient innovation processes and thus related firms' output.

The results of the research could be interesting to the countries that experienced similar socio-economic changes, i.e. the dismantling of the mutual market and slow enterprises' reorientation to exports, where the main current challenge for their innovation/industrial policy in the context of the Smart Specialisation Strategy (S3) was to establish clear prioritisation in terms of the thematic areas. These include the selected South East European countries as prospective EU members, such as Serbia, Macedonia, Montenegro and Moldavia, since their prerequisite for EU accession is the implementation of S3.

\section{LIMITATIONS}

One of the most influencing limitations is the personal perception of respondents related to the researched area, both in firms and in the institutional framework. In the analysis, the collected responses were equally treated and evaluated. Since these persons occupy different hierarchical positions, possess various skills and cognitive capabilities, it is plausible that they understand and perceive the prioritisation ranking factors. However, due to the bias in their perceptions, this perhaps contributed to inaccuracy in the analysis. This limitation was mitigated by structuring and articulating the ranking questions in the simplest possible formulation, while still maintaining their soundness and relevance.

\section{FUTURE RESEARCH}

Empirical results of this work provide acceptable methodological and knowledge ground for future extension in researching the innovation policy mix measures and instruments. Expanding the scope of research towards the integrated policy mix which would include both the supply- and demand-side policy is most promising. The results provided in this research may serve as a background for comparative research at the regional level or with a broader international scope. 
DRUŠ. ISTRAŽ. ZAGREB GOD. 27 (2018), BR. 4 STR. $649-669$

VLAČIĆ, E., DABIĆ, M. ARALICA, Z.

NATIONAL...

\section{NOTES}

\section{REFERENCES}

Furthermore, the results may be comparable with other EU (and non-EU) countries and thus provide an expanded implementation of this research. With regard to the targeted population, a subsequent research focus can be on the firms that operate in different industry sectors, that compete for innovation financial support within the sectors defined by Smart Specialization (MINGO, 2016).

1 Croatian Agency for SMEs, Innovations and Investments

2 Founded in 2012. ZIP has established itself as the strongest startup incubator in Croatia.

${ }^{3}$ For more information about Spearman Rank Correlation Coefficient, please see Zar (1971).

4 The basic significance graph on which the present data are plotted is presented at http://geographyfieldwork.com/SpearmansRank.htm

Allocca, M. A., \& Kessler, E. H. (2006). Innovation speed in small and medium-sized enterprises. Creativity and Innovation Management, 15(3), 279-295. https://doi.org/10.1111/j.1467-8691.2006.00389.x

Bartlett, W. (2014). Shut out? South East Europe and the EU's New Industrial Policy. LEQS Paper No. 84. Available at https://papers.ssrn.com/sol3/ papers.cfm?abstract_id $=2534513$

Becker, W., \& Dietz, J. (2004). R\&D cooperation and innovation activities of firms - evidence for the German manufacturing industry. Research Policy, 33(2), 209-223. https://doi.org/10.1016/j.respol.2003.07.003

Borrás, S., \& Edquist, C. (2013). The choice of innovation policy instruments. Technological Forecasting and Social Change, 80(8), 1513-1522. https://doi.org/10.1016/j.techfore.2013.03.002

Božić, Lj., \& Rajh, E. (2016). The factors constraining innovation performance of SMEs in Croatia. Economic Research - Ekonomska istraživanja, 29(1), 314-324. https://doi.org/10.1080/1331677X.2016.1168040

Brautzsch, H.-U., Jutta, G., Loose, B. et al. (2015). Can R\&D subsidies counteract the economic crisis? - Macroeconomic effects in Germany. Research Policy, 44, 623-633. https://doi.org/10.1016/j.respol.2014.11.012

Chicot, J., \& Matt, M. (2015). Rationales of public procurement of innovation: When demand-side instruments address supply-side gaps. Research Policy, 36(949â), 963.

Craft, R. C., \& Leake, C. (2002). The Pareto principle in organizational decision making. Management Decision, 40(8), 729-733. https://doi.org/ 10.1108/00251740210437699

Dabić, M., Razum, A., \& Brečić, R. (2016). Product and process Innovation - A cross country comparison between Croatia, Poland and the UK. European Journal of Economics and Management, 3, 74-86.

Dodgson, M. (2017). Innovation in firms. Oxford Review of Economic Policy, 33(1), 85-100. https://doi.org/10.1093/oxrep/grw034 
DRUŠ. ISTRAŽ. ZAGREB GOD. 27 (2018), BR. 4, STR. 649-669

VLAČIĆ, E., DABIĆ, M. ARALICA, Z. NATIONAL..
Durst, S., \& Poutanen, P. (2013). Success factors of innovation ecosystems: Initial in-sights from a literature review. In R. Smeds, \& O. Irrmann (Eds.), Co-create 2013: The Boundary-Crossing Conference on Co-Design in Innovation. Aalto, Denmark, 27-38. Available at http://www. academia.edu/4007245/Success_factors_of_innovation_ecosystems_ A_literature_review

Edler, J., \& Georghiou, L. (2007). Public procurement and innovation - Resurrecting the demand side. Research Policy, 36(7), 949-963. https://doi.org/10.1016/j.respol.2007.03.003

Edler, J., \& Fagerberg, J. (2017). Innovation policy: What, why, and how. Oxford Review of Economic Policy, 33(1), 2-23. https://doi.org/10.1093/ oxrep/grx001

Edquist, C. (2005). Systems of innovation: Perspectives and challenges. In J. Fagerberg, D. C. Mowery, \& R. Nelson (Eds.), The Oxford handbook of innovation (pp. 181-208). New York, Oxford: University Press.

Edquist, C. (2011). Design of innovation policy through diagnostic analysis: Identification of systemic problems (or failures). Industrial and Corporate Change, 20(6), 1725-1753. https://doi.org/10.1093/icc/dtr060 EIS (2017). The European innovation scoreboard. European Commission. Available at https://www.rvo.nl/sites/default/files/2017/06/European_ Innovation_Scoreboard_2017.pdf

Hazelman, V. A. R. (2017). Innovation from a distance: A study of diffusion in a regional university. (Doctor of Philosophy thesis). School of Education, University of Wollongong. Available at http://ro.uow.edu. $\mathrm{au} /$ theses $1 / 45$

Horbach, J., Rammer, C., \& Rennings, K. (2012). Determinants of eco-innovations by type of environmental impact - The role of regulatory push/pull, technology push and market pull. Ecological Economics, 78, 112-122. https://doi.org/10.1016/j.ecolecon.2012.04.005

Howlett, M., \& Rayner, J. (2007). Design principle for policy mixes: Cohesion and coherence in new governance arrangements. Policy and Society, 26(4), 1-18. https://doi.org/10.1016/S1449-4035(07)70118-2 Ireland, R. D., \& Webb, J. W. (2007). Strategic entrepreneurship: Creating competitive advantage through streams of innovation. Business Horizons, 50(1), 49-59. https://doi.org/10.1016/j.bushor.2006.06.002

Isenberg, D. J. (2010). The big idea: How to start an entrepreneurial revolution. Harvard Business Review, 88(6), 40-50.

JRC IPTS (2015). RIO Country Report 2015: Croatia. Available at https://rio. jrc.ec.europa.eu/en/library/rio-country-report-croatia-2015

JRC IPTS (2013). ERAWATCH Country Report 2011 - Croatia. Available at https://rio.jrc.ec.europa.eu/en/library/erawatch-country-report-croatia2011

Karuppusami, G., \& Gandhinathan, R. (2006). Pareto analysis of critical success factors of total quality management: A literature review and analysis. The TQM Magazine, 18(4), 372-385. https://doi.org/10.1108/ 09544780610671048

Kiessling, T. S., Richey, R. G., Meng, J., \& Dabić, M. (2009). Exploring knowledge management to organizational performance outcomes 
DRUŠ. ISTRAŽ. ZAGREB GOD. 27 (2018), BR. 4 STR. $649-669$

VLAČIĆ, E., DABIĆ, M. ARALICA, Z.: NATIONAL... in a transitional economy. Journal of World Business, 44(4), 421-433. https://doi.org/10.1016/j.jwb.2008.11.006

Komninos, N., \& Tsamis, A. (2008). The system of innovation in Greece: Structural asymmetries and policy failure. International Journal of Innovation and Regional Development, 1(1), 1-23. https://doi.org/10.1504/ IJIRD.2008.016857

Landabaso, M., \& Mouton, B. (2005). Towards a different regional innovation policy: Eight years of European experience through the European Regional Development Fund innovative actions. In M. van Geenhuizen, D. V. Gibson, \& M. V. Heitor (Eds.), Regional development and conditions for innovation in the network society. Regional development and conditions for innovation in the network society (pp. 209-240). New York and Canada: Routledge.

Mazzucato, M., \& Semieniuk, G. (2017). Public financing of innovation: New questions. Oxford Review of Economic Policy, 33(1), 24-48. https://doi. org/10.1093/oxrep/grw036

Meissner, D., \& Carayannis, E. G. (2017). Value generation from industry-science linkages in light of targeted open innovation. Journal of Knowledge Management, 21(2), 295-307. https://doi.org/10.1108/JKM11-2016-0510

Mercan, B., \& Göktaş, D. (2011). Components of innovation ecosystems: A cross-country study. International Research Journal of Finance and Economics, (76), 102-112.

MINGO (2014). Strategija poticanja inovacija Republike Hrvatske 2014. - 2020. [Smart specialisation strategy S3 of Republic of Croatia 2014-2020]. Official Gazette, vol. 153, no. 74/2014.

MINGO (2016). Strategija pametne specijalizacije Republike Hrvatske za razdoblje 2016.-2020. [Smart specialisation strategy S3 of Republic of Croatia 2014-2020]. Official Gazette, vol. 2, no. 2/2016.

Mulrow, J. S., Derrible, S., Ashton, W. S., \& Chopra, S. S. (2017). Industrial symbiosis at the facility scale. Journal of Industrial Ecology, 21(3), 559-571. https://doi.org/10.1111/jiec.12592

OECD (2012). OECD Science, Technology and Industry Outlook 2012. Available at https://www1.oecd.org/media/oecdorg/satellitesites/stieoutlook/files/policyprofile/STI\% 20Outlook\%2012_\%20PP\%20Actors _Innovation\%20Policy\%20Mix.pdf https://doi.org/10.1787/19991428

OECD (2014). OECD Science, Technology and Industry Outlook 2014. OECD Publishing. Available at https://www.oecd.org/sti/outlook/eoutlook/stipolicyprofiles/competencestoinnovate/innovationpolicy mixforbusinessrdandinnovation.htm

Osei-Kyei, R., \& Chan, A. P. (2015). Review of studies on the critical success factors for Public-Private Partnership (PPP) projects from 1990 to 2013. International Journal of Project Management, 33(6), 1335-1346. https://doi.org/10.1016/j.ijproman.2015.02.008

Perrels, A. (2001, October). Efficiency and effectiveness of policy instruments: Concepts and practice. In Workshop on Good Practices in Policies and Measures (Vol. 8, p. 10). 
DRUŠ. ISTRAŽ. ZAGREB GOD. 27 (2018), BR. 4, STR. 649-669

VLAČIĆ, E., DABIĆ, M. ARALICA, Z. NATIONAL..
Radosevic, S., \& Yoruk, E. (2013). Entrepreneurial propensity of innovation systems: Theory, methodology and evidence. Research Policy, 42(5), 1015-1038. https://doi.org/10.1016/j.respol.2013.01.011

Spigel, B. (2017). The relational organization of entrepreneurial ecosystems. Entrepreneurship Theory and Practice, 41(1), 49-72. https://doi. org/10.1111/etap.12167

Švarc, J. (2006), Socio-political factors and the failure of innovation policy in Croatia as a country in transition. Research Policy, 35(1) 144-159.

Van Der Borgh, M., Cloodt, M., \& Romme, A. G. L. (2012). Value creation by knowledge-based ecosystems: Evidence from a field study. RED Management, 42(2), 150-169. https://doi.org/10.1111/j.1467-9310. 2011.00673.x

Vlačić, E., Tišma, S., \& Maleković, S. (2005). The competitiveness of national (Croatian) economies through development of industrial cluster. Croatian International Relations Review, 11(38/39), 15-28.

Wilson, K. E. (2015). Policy lessons from financing innovative firms. OECD Science, Technology and Industry Policy Papers, No. 24, OECD Publishing, Paris. https://doi.org/10.1787/5js03z8zrh9p-en

Zar, J. H. (1971). Significance testing of the spearman rank correlation coefficient. Journal of the American Statistical Association, 67(339), 578-580.

Zhu, K., Dong, S., Xu, S. X., \& Kraemer, K. L. (2006). Innovation diffusion in global contexts: Determinants of post-adoption digital transformation of European companies. European Journal of Information Systems, 15(6), 601-616. https://doi.org/10.1057/palgrave.ejis.3000650

\section{Nacionalni inovacijski sustav: u čemu se vlada i poslovni sektor razlikuju?}

Ernest VLAČIĆ

NOVAMINA, Centar inovativnih tehnologija d.o.o., Zagreb

Visoko učilište ALGEBRA, Zagreb

Marina DABIĆ

Ekonomski fakultet, Zagreb

Fakultet poslovne ekonomije, Nottingham, Velika Britanija

Zoran ARALICA

Ekonomski institut, Zagreb

Rad istražuje nacionalni inovacijski sustav i divergenciju prioriteta ključnih mjera nacionalnoga institucionalnog okvira, povezanih s kombinacijom ponuđenih miera politike na strani ponude. Za analizu su odabrane dvije skupine unutar Hrvatske: s jedne strane trideset tri (33) predstavnika državnih institucija, kao predstavnika institucionalnog okvira ekosustava, a s druge devedeset tri (93) vlasnika ili direktora poduzeća na koje se odnose ciljevi politike te korisnici mjera. 
DRUŠ. ISTRAŽ. ZAGREB GOD. 27 (2018), BR. 4 STR. 649-669

VLAČIĆ, E., DABIĆ, M., ARALICA, Z

NATIONAL.
Rezultati su bili dodatno provjereni upotrebom osamnaest (18) polustrukturiranih intervjua s predstavnicima raznih vladinih tijela, kao i s predstavnicima institucionalnog okvira. Rezultati potvrđuju razlike u percepciij važnosti i relevantnosti te kombinaciju potrebnih miera državne politike između dviju populacija.

Ključne riječi: Nacionalni inovacijski sustav - NIS, državne politike, strana ponude, Hrvatska

\section{(c) (1) (5)}

Međunarodna licenca / International License:

Imenovanje-Nekomercijalno / Attribution-NonCommercial 